
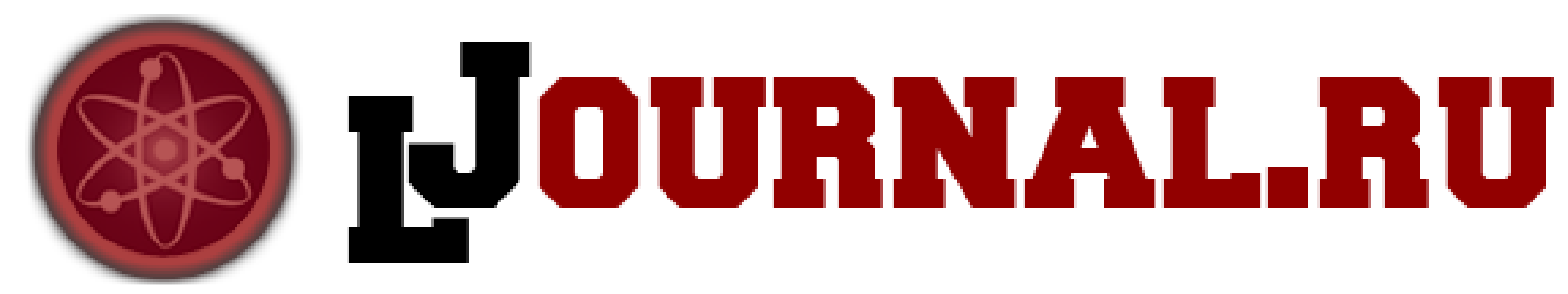

Садыкова А.P. ГАОУ ВО МГПУ Россия, Москва

doi: 10.18411/1j2016-2-22

\title{
Содержательный анализ педагогического текста педагогом исследователем
}

Многие считают, что педагог-исследователь априори владеет соответствующим процессуальным инструментарием, - однако, наш опыт показывает обратное: и сами тексты часто далеки от соответствия критерию адекватного смыслового восприятия читателями, и читатели испытывают трудности в процессе интерпретации содержания текстов и продуктивной реализации полученной при чтении информации в собственной научной деятельности.

Полагаем, важным - информационный компонент анализа текстов, представленный подробно, например, в книге А.В. Коржуева и А. Р. Садыковой «Общенаучные основания педагогики и педагогического поиска» [2].

Рефлексивный компонент анализа педагогических источников предполагает конкретизацию педагогом-исследователем авторского замысла, обличению его в конкретные, «осязаемые» формы, в которых проявляется та или иная степень новизны проектируемого подхода, степень его отличия от того, что уже сделано, выявление таких элементов в исследованиях предшественников, по которым начинающий диссертант готов представить собственные возражения, опровержения, альтернативные выводы или заключения [6]. 
Одной из значимых составляющих содержательного анализа является анализ концептуальной направленности педагогического продукта - под этим мы понимаем систему исходных положений, на которые опирается автор исследуемого текстового продукта и совокупность стержневых, базовых, основополагающих идей, на которых он строит свое дальнейшее рассмотрение $[1]$.

Отметим, что содержательный анализ педагогического текста предполагает и выявление аспектной определенности рассмотрения, предпринятого автором анализируемого источника, выявление того ракурса, того угла зрения, под которым он исследует педагогические объекты, феномены и особенности их протекания в конкретном сегменте педагогической действительности.

Содержательный анализ помимо того, о чем уже было выше упомянуто, предполагает и выявление реципиентом области применимости и степени однозначности выводов автора анализируемого текста и в итоге могут быть возможными несколько сюжетов: во-первых, читатель может конкретно определить, каким образом необходимо сузить, ограничить область применимости полученных и описанных в тексте результатов; во-вторых, наложить ограничение на «читаемый» вывод или результат в виде выявления и обоснования одного или нескольких дополнительных условий; в-третьих, предложить альтернативу тем подходам и технологиям, которые автор рецензируемого и осмысливаемого текста предлагает внедрить для достижения определенной положительной динамики в образовательном процессе.

В предпринятом нами рассмотрении нельзя не коснуться еще одного важного аспекта, связанного с тем, что сегодня содержательный анализ в педагогике выполняет функцию поиска методов реконструкции смыслов, заложенных в текстах самими их авторами, а также поиска реципиентами новых, первоначально скрытых смыслов - посредством эмпатии, глубокого «вчувствования» в читаемое, рефлексии логики изложения результатов и ее 
соотнесения с логикой существования и развития описываемых автором текста объектов и феноменов окружающей действительности.

Перейдем от содержательного к логическому компоненту рефлексии педагогического текста и позиционируем в качестве основной процедуры реконструкцию читателем логики рассуждений автора анализируемого текста. Подробно этот аспект обсуждался на страницах журнала «Педагогика» в статье B.А. Попкова и А.В. Коржуева «Некоторые логические операции в педагогическом исследовании» [3].

Все обсужденное выше позволяет нам утверждать, что рефлексивный компонент анализа педагогического текста проявляет и значимую конструктивную составляющую, что выражается:

- в том, что обозначенные в источниках или самостоятельно выявленные на основе анализа текста противоречия педагогической действительности становятся для начинающего автора основой или отправной точкой собственного исследования;

- в том, что обозначенные выше противоречия могут привести реципиента к нахождению одного или нескольких их «производных», на которых сам автор рецензируемого текста явно не акцентировал свое и читательское внимание;

- в том, что обсужденное в статье осмысление читателем способов текстового представления авторами собственных мыслей и процесса их развития формирует у него соответствующие умения по отношению к собственной деятельности аналогичной направленности;

- в том, что анализ текста, сочетающий все обсужденные в статье процедуры, формирует у педагога-исследователя креативное начало, собственный педагогический стиль и неповторимый индивидуальный, авторский научный подход. 


\section{Литература:}

1. Коржуев А.В., Садыкова А.Р. Общенаучные основания педагогики и педагогического поиска. - М.: Изд-во «ЛИБРОКОМ» (urss), 2010.

2. Коржуев А.В., Садыкова А.Р. Педагогический поиск: теория, методология, прикладные аспекты. - М.: Изд-во «ЛИБРОКОМ», 2013.

3. Попков B.A., Коржуев А.В. Некоторые логические операции в педагогическом исследовании // «Педагогика», №7, 2013, с. 50 - 59.

4. Рузавин Г.И. Методология научного познания. - М.: Юнити-Дана, 2005.

5. Садыкова А.Р., Икренникова Ю.Б., Ефимушкина С.В. Эвристическое образование педагога вуза и многоуровневая система образования. Вестник науки. Сборник научных работ преподавателей, аспирантов и студентов физико-математического факультета Орловского государственного университета. Выпуск 3. - Орел: Издательство Орловского государственного университета, Полиграфическая фирма «Картуш», 2013., с.80-82.

6. Садыкова А.Р. Рефлексивность - неотъемлемое качество мышления конкурентоспособного специалиста. Сборник научных трудов XIII Международной научно-методической конференции. Выпуск 11, том 1. - М.: МГУТУ, 2007, с. 237-241. 